\title{
JOURNAL.RU
}

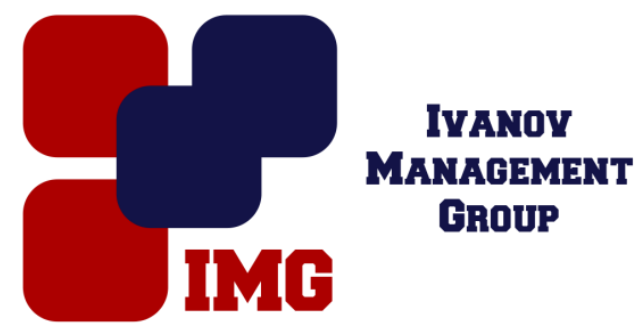

\author{
Валынов А.С., Чиркова Н.В., Вечеркина Ж.В., Чиркова К.Е. \\ Воронежский государственный медицинский университет имени Н. Н. Бурденко \\ Воронеж, Россия
}

doi: 10.18411/lj-30-06-2017-06

idsp 000001:1j-30-06-2017-06

\section{Повышение качества фиксации несъемных конструкций зубных протезов путем модификации фиксирующих материалов наноразмерными частицами кремния}

Одной из причин преждевременного нарушения фиксации, приводящее к разгерметизации конструкций несъемных зубных протезов, является отсутствие фиксирующих материалов, полностью отвечающих требованиям и обеспечивающих надежное удержание протезов на опорных зубах. В последние годы существенно расширилась область применения стеклоиономерных цементов. Фиксирующие материалы данной группы имеют ряд преимуществ, начиная от простоты использования, и заканчивая высокой прочностью и степенью адгезии к металлу и тканям зуба. Однако все больше стоматологовортопедов отдают предпочтение зарубежным стеклоиономерным материалам.

Цель - изучить свойства отечественного стеклоиономерного цемента, модифицированного наноразмерными частицами кремния.

Для сравнительной оценки использовали образец исходного фиксирующего материала «Целит-Иономер ФХ» и «опытный образец с добавлением наноразмерных частиц кремния в количестве $0,005 \%$, по массе к порошку к отечественному материалу.

Исследования физико-механических свойств фиксирующих материалов проводили согласно общепринятым требованиям к стоматологическим цементам на базе ООО «Целит» г. Воронеж. Определяли следующие показатели: прочность на сжатие, время твердения материалов, толщина образуемой плёнки фиксирующего материала, растворимость материалов в жидкостях и адгезионная способность к дентину зуба. Клиническая оценка материалов 
заключалась в обследовании и лечении 40 человек в возрасте от 25 до 55 лет с диагнозом «Дефект твёрдых тканей зубов, ИРОПЗ 0,6-0,7».

При модификации стеклоиономерного фиксирующего материала наноразмерными частицами кремния в соотношении $0,005 \%$ по массе к порошку происходят положительные изменения физико-механических свойств по сравнению с исходным материалом, заключающиеся в увеличении прочности при сжатии на 20-25 единиц, увеличении в 1,5 раза силы адгезии к дентину зуба, уменьшении толщины пленки материала в среднем на 6 мкм. Добавление наноразмерных частиц кремния в соотношении 0,005\% по массе к порошку приводит к увеличению времени твердения, что напрямую положительно влияет на рабочее время фиксирующего стеклоиономерного материала.

Анализ клинических наблюдений результатов лечения больных несъемными конструкциями зубных протезов, фиксированными с применением модифицированного материала наноразмерными частицами кремния в соотношении $0,005 \%$ по массе к порошку в период от полугода до года, показал отсутствие нарушения фиксации, изменения краевого прилегания и отрицательного воздействия на ткани пародонта.

\section{Литература}

1. Клинико-экономическая эффективность использования модифицированных фиксирующих материалов / А. Н. Морозов, Ж.В. Вечеркина, Н.В. Чиркова, В.С. Калиниченко // Системный анализ и управление в биомедицинских системах. - 2014. T.13, №2. - C.364-365.

2. Субъективная оценка пациентами качества фиксации несъемных конструкций зубных протезов / Ж.В. Вечеркина, Н.В. Чиркова, Н.В. Калиниченко, М.А. Крючков // Системный анализ и управление в биомедицинских системах. - 2015. - Т.14, №1. C.83-85.

3. Чиркова Н.В. Нанокремний в стоматологии / Н.В. Чиркова, А.А. Кунин, Е.А. Лещева // Монография. - Воронеж: ГБОУ ВПО «Воронежская государственная медицинская академия им. Н.Н. Бурденко» Министерства здравоохранения Российской Федерации, 2013. $-107 \mathrm{c}$. 